\title{
Tsunami hazard in the shorelines of Khark island (Persian Gulf), Iran*
}

\author{
Mehdi Zaré ${ }^{1, *}$ Seyed-Ahmad Hashemi ${ }^{1} \quad$ Roya Ebadi $^{1}$ \\ Sahar Amirnejad-Mojdehi ${ }^{1}$ Roya Rahmani ${ }^{1}$ and Ali Sardar ${ }^{2}$ \\ ${ }^{1}$ International Institute of Earthquake Engineering and Seismology, Tehran 19395/3913, Iran \\ ${ }^{2}$ Iranian Oil Terminals Company, Tehran 15549/18417, Iran
}

\begin{abstract}
Iran is located in one of the seismically active regions of the world. Due to the high probability of earthquakes throughout the country and the potential for tsunami inundation along the coasts and offshore, comprehensive studies on the interaction of these natural phenomena are necessary. In this study, the most conservative scenarios are determined for possible earthquakes within the Khark zone (Persian Gulf) based on experimental relations between the fault length, magnitude and displacement, which are parameters for determining tsunamigenic sources. Subsequently, the maximum height of tsunami waves are calculated based on the specifications of the seismic source and its distance from the shore as well as the coastal slope. A zoning map of tsunami hazard is finally presented.
\end{abstract}

Key words: tsunami; Khark island; seismotectonic; seismic source

CLC number: P315.9 Document code: A

\section{Introduction}

The goal of this research was to conduct seismic hazard analysis so as to assess the tsunami hazard of Khark island as a part of seismic retrofitting of the oil terminals located on the island. Khark island is located in the northern part of the Persian Gulf $\sim 57 \mathrm{~km}$ northwest of Boushehr, between the longitude of $50^{\circ} 16^{\prime} \mathrm{E}$ to $50^{\circ} 19^{\prime} \mathrm{E}$ and latitude $29^{\circ} 11^{\prime} \mathrm{N}$ to $29^{\circ} 14^{\prime} \mathrm{N}$. Khark island is $3.7 \mathrm{~km}$ southwest of Kharkoo island and $\sim 38 \mathrm{~km}$ from the port of Genaveh in Iran.

The oldest deposits found on Khark island are Pliocene in age and consist of the upper Aghajari formation or Lahbari member (LBM in Figure 1), which are composed of siltstone and colored marls. The Bakhtiari conglomerate (BK in Figure 1) and Khark limestone (LBM in Figure 1) are contained within the Pliocene strata. Although these two layers are coeval, they differ in facies, and the latter is covered by $5 \mathrm{~m}$ of marine sand

\footnotetext{
* Received 30 April 2012; accepted in revised form 25 June 2012; published 10 August 2012.

† Corresponding author. e-mail: mzare@iiees.ac.ir

(c) The Seismological Society of China, Institute of Geophysics,

China Earthquake Administration, and Springer-Verlag Berlin Heidelberg 2012
}

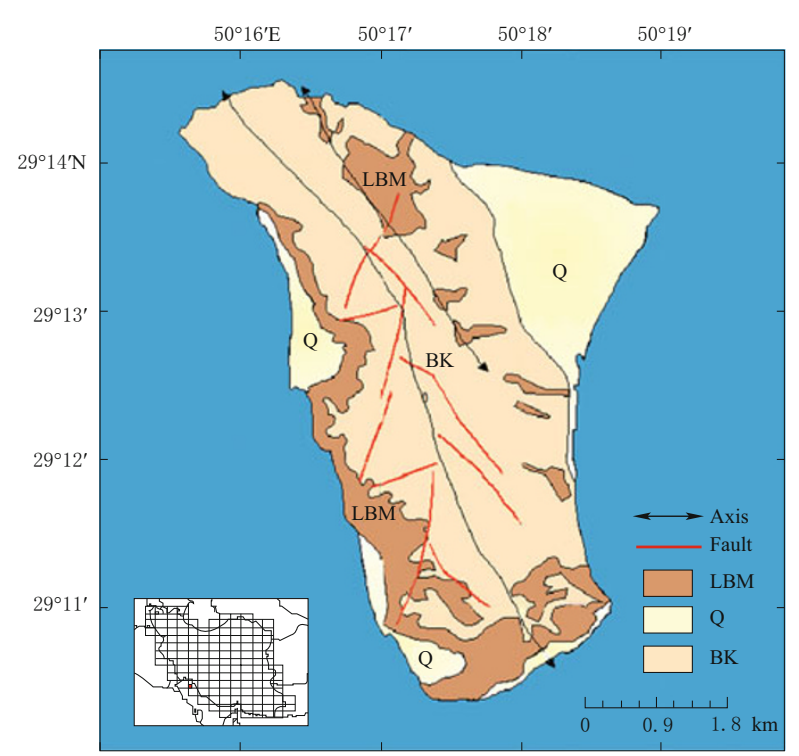

Figure 1 Geological map of Khark island where LBM denotes Lahbari member, Q denotes Quaternary, and BK denotes Bakhtiari formation.

(Q in Figure 1).

Although no geohazard studies of Khark island have previously been published, a geological map, which summarizes the location and distribution of faulting and geological units, can be found in a general geologi- 
cal compilation report on the Zagros mountains (Motie, 1993). In this study the assessment of the seismic hazard is explained first, based on the determination of seismic source zones. Secondly, we calculate the possible water wave height along the shorelines of the Khark island caused by any probable tsunami in the Persian Gulf. The deterministic approach applied in this study is based on the approach laid out by the Iranian Oil Terminals Company (OTC), who will be the end user of this study. The specification of the present study is focused on the tsunami hazard analysis for the shorelines of the Khark island, which is one of the first attempts to quantify the tsunami hazard in the Persian Gulf.

\section{Seismotectonic of the region}

The most recent orogenic event (Pasadenian), recorded on Khark island, caused tectonic folding of the island and development of two mappable anticlines. Both anticlines trend NW-SE with the southern fold extending the entire length of the island, whereas the northern fold is only present in the northeast corner of the island. Continued convergence between the Arabian and the Iranian plates, has resulted in deformation of young deposits on Khark island and earthquakes in the region.

\section{Tsunami phenomenon}

The principal tsunami source comes from earthquakes generated on faults that are offshore beneath the Persian Gulf. Attempts have been made to model the effects of earthquakes that occur above sea level on generating tsunamis (Yanovskaya et al., 2003); however, the transmission of earthquake energy to water is not clear at present. In this study only the seismic sources that are located offshore and affect the seabed are studied. The tsunami characteristics mostly depend on the seismic parameters of the earthquake that caused it. The most important parameters are the seismic moment, focal mechanism and focal depth of the earthquake. Moreover, the depth of water where the earthquake happened is an important factor because the water volume affected by the earthquake is significantly affective in the energy of occurred tsunami.

\section{Tsunami hazard analyses}

Determination of the event probability is critical in all comprehensive hazard analysis. This is especially true in tsunami risk. Previous attempt have been per- formed using the deterministic method and using scenarios (Soloviev, 1970; Soloviev, 1978; Murty, 1977; Yanovskaya et al., 2003).

Probabilistic tsunami hazard analysis (PTHA) is established based on probabilistic seismic hazard analysis (PSHA) and combines two calculating and experimental methods of historical run-ups. The main difference between PTHA and PSHA is that far sources are considered in the latter. The calculating methods are mainly based on the numerical modeling of tsunami wave distribution. In PSHA, the attenuation relation is used for determining the ground motions. As both source and local parameters (special topography of seabed and shore) affect the local run-up level, PTHA can be more complex than PSHA.

\subsection{Bathymetry of Khark island zone}

With the exception of the west side of Khark island, water depth studies show that the island slopes gently to a depth of $3 \mathrm{~m}$. The width of this slope extends outward from the shore for $\sim 500 \mathrm{~m}$ from the shore and reaches to its maximum in the northeast and south shores (Figure 2). The water depth increases faster in the north, whereas along the eastern and southern coasts the water depth reaches $15 \mathrm{~m}$ at a distance of $3 \mathrm{~km}$. However, along the western coast the slope is steeper than elsewhere on the island, reaching depths of $20 \mathrm{~m}$ at a distance of $200 \mathrm{~m}$ from the shore and a depth of $40 \mathrm{~m}$ at a distance of $1 \mathrm{~km}$. The deepest points around the island are $30-40 \mathrm{~m}$ and lie west of the island (Figure 2).

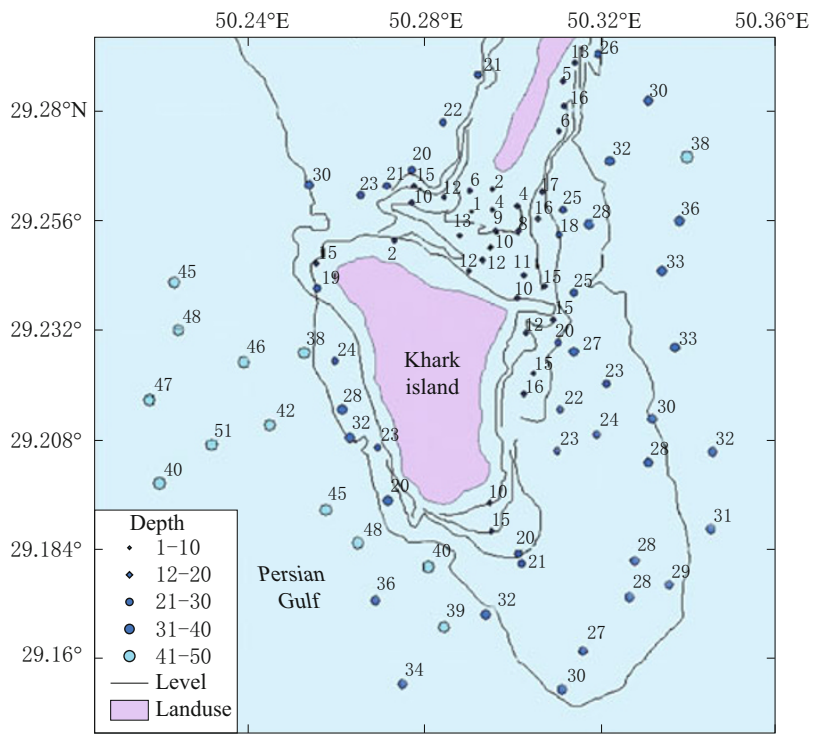

Figure 2 Bathymetry map of Khark island where the numbered points give estimated water depth in meters. 


\subsection{Determination of seismic source zones}

The faults and tectonic trends of the study area are investigated using geological maps and relevant available published research. This information was compiled into a single structural map (Figure 3).

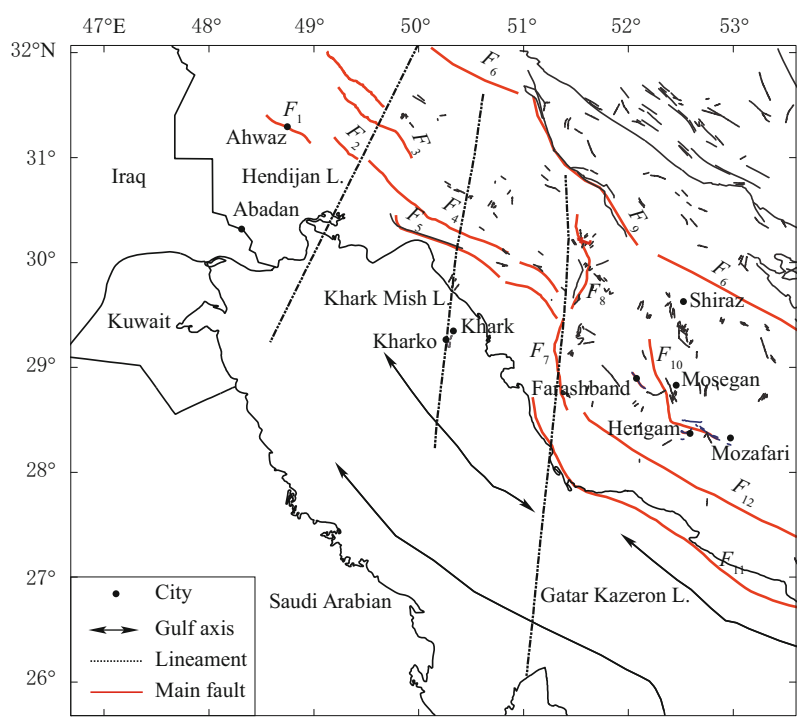

Figure 3 Tectonic map of the main faults on Khark island area. $F_{1}$. Ahvaz fault; $F_{2}$. Maron fault; $F_{3}$. Ramhormoz fault; $F_{4}$. Aghajari fault; $F_{5}$. Rage sefid fault; $F_{6}$. HZF; $F_{7}$. Borazjan fault; $F_{8}$. Gazeron fault; $F_{9}$. Dena fault; $F_{10}$. Korebas fault; $F_{11}$. Zagros frontal fault; $F_{12}$. Mountain Front Flexure.

The Kazeroon-Borazjan, Khark-Mish and Hendijan faults are considered to be the potential tsnamigenic sources due to their proximity to Khark island. Although the Makran subduction zone was far from the study site, it was considered in the calculations due to its seismic significance and being the interpreted source of a tsunami on 27 November 1945 (Figure 4).

Following digitization of the faults, the expected magnitudes for these structures was calculated using empirical relationships defined by previous researches (Zaré, 2003a, b; Mohajer-Ashjai and Nowroozi, 1978; Nowroozi and Mohajer-Ashjai, 1985; Wells and Coppersmith, 1994; Ambraseys and Jackson, 1998). The maximum and median probable slips of these faults are obtained by applying the relations of Wells and Coppersmith (1994) and Liu-Zeng et al. (2005) (Table 1).

Due to the lack of focal mechanism and fault type data, the worst-case scenario has been assumed, where strike-slip faults are interpreted to have vertical fault planes. Therefore, it is assumed that the maximum slip on the fault has happened (Ward, 2002). In addition the slide distribution is assumed homogenous along the fault.

In the cases where linear sources are substituted for point sources, the maximum height of the tsunami is not significantly affected. Therefore, the least distance from the source is taken as the tsunami wavelength for any point (Ward, 2002).

\subsection{Model structure}

The relation between the wave heights $(H)$ in the source and coast is

$$
H_{\mathrm{c}}=f\left(H_{\mathrm{s}}, r, h_{\mathrm{c}}, h_{\mathrm{s}}, \alpha\right)
$$

where $H_{\mathrm{c}}$ is the height of wave in the coast, $H_{\mathrm{s}}$ is the height of wave in the source, $h_{\mathrm{c}}$ is median depth of the coast, $h_{\mathrm{s}}$ is the depth of source, $r$ is the distance from coastal point to the source and $\alpha$ the slope of coastal profile.

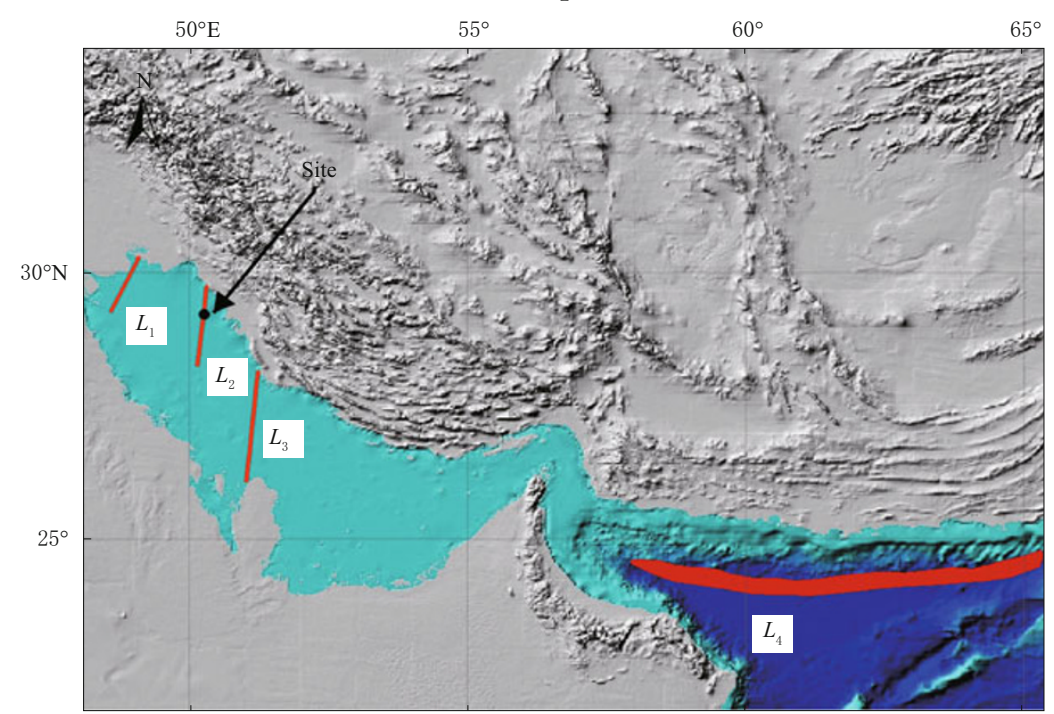

Figure 4 Tsunamigenic source map with respect to the source $L_{2}$. 
Table 1 Magnitude and slip variables for each potential tsunamigenic fault

\begin{tabular}{|c|c|c|c|c|c|c|c|c|c|c|}
\hline \multicolumn{2}{|c|}{ Source } & \multicolumn{6}{|c|}{ Magnitude $M$} & \multicolumn{3}{|c|}{ Slip $S / \mathrm{m}$} \\
\hline Name & $\begin{array}{l}\text { Length } \\
/ \mathrm{km}\end{array}$ & $\begin{array}{c}\text { Wells \& } \\
\text { Coppersmith } \\
\text { (1994) }\end{array}$ & $\begin{array}{c}\text { Nowroozi \& } \\
\text { Mohajer-Ashjai } \\
(1985)\end{array}$ & $\begin{array}{c}\text { Ambraseys \& } \\
\text { Jackson } \\
\text { (1998) }\end{array}$ & $\begin{array}{c}\text { Mohajer-Ashjai \& } \\
\text { Nowroozi } \\
(1978)\end{array}$ & $\begin{array}{c}\text { Zare } \\
(2003 a, b)\end{array}$ & $M_{\mathrm{av}}$ & $\begin{array}{c}\text { Wells \& } \\
\text { Coppersmith } \\
\text { (1994) }\end{array}$ & $\begin{array}{l}\text { Liu-Zeng } \\
\text { et al. (2005) }\end{array}$ & $S_{\mathrm{av}}$ \\
\hline$L_{1}$ & 151 & 7.2 & 7.3 & 7.2 & 7.3 & 8.2 & 7.4 & 0.8 & 4.5 & 2.7 \\
\hline$L_{2}$ & 169 & 7.3 & 7.4 & 7.3 & 7.3 & 8.3 & 7.5 & 0.9 & 5.1 & 3.0 \\
\hline$L_{3}$ & 245 & 7.5 & 7.6 & 7.4 & 7.5 & 8.6 & 7.7 & 1.1 & 7.3 & 4.2 \\
\hline$L_{4}$ & 690 & 8.2 & 8.1 & 7.9 & 7.9 & 9.5 & 8.3 & 1.5 & 20.7 & 11 \\
\hline
\end{tabular}

Near the coastline, the water depth decreases and the wave length increases, which is referred to as "runup". For shallow depths the linear theory of the waves is shown as (Ward, 2002)

$$
S_{L}(\omega, r)=\sqrt{\frac{u(\omega, h(r))}{u\left(\omega, h_{\mathrm{s}}\right)}},
$$

where $S_{L}$ is the shallow depth factor, and its value depends on the difference between the group velocity of the waves at the tsunami source $u(\omega, h(r))$ and at the coastline $u\left(\omega, h_{\mathrm{s}}\right)$. In uniform water depth the shallow depth factor, $S_{L}$, similar to the geometric expansion factor, $G(r)$, will be 1 . The short period coastal waves $(\sim 10 \mathrm{~s})$ show $<50 \%$ increase in amplitude. However tsunami waves with the periods of 100 to $2000 \mathrm{~s}$ have shallow wave factors between 3 and 6 . For the water waves with a period of more than 250 seconds, we have

$$
d_{C} \gg h \quad u(\omega, h)=(g h)^{1 / 2}
$$

and

$$
u\left(\omega, h_{\mathrm{s}}\right)=\left(g h_{\mathrm{s}}\right)^{1 / 2} .
$$

Consequently, the shallow depth factor $S_{L}$ will be

$$
S_{L}=\sqrt[4]{\frac{h}{h_{\mathrm{s}}}}
$$

Based on Green's law, the shallow water factors $h_{\mathrm{c}}$ and $h_{\mathrm{s}}$ become

$$
\frac{H_{\mathrm{c}}}{H_{\mathrm{s}}} \approx \sqrt[4]{\frac{h_{\mathrm{c}}}{h_{\mathrm{s}}}}
$$

\subsection{Geometric expansion effects}

Due to the geometric distribution, the attenuation differs from $r^{-1}$ distant for short waves to $r^{-0.5}$ for long waves. The minimum wavelength of tsunami is three times as long as the water depth on the source and its maximum depends on the dimension of rupture.

The maximum wavelength of tsunami could not be determined for these sources due to a lack or unavailability of data. Therefore, the type of tsunami wave has been determined based on the assumption of direct relations between the tsunami wavelength and the causative earthquake magnitude. Takahasi (1961) studied the earthquakes and their consequent tsunamis, and concluded that the dominant tsunami per minute periods had a close relationship with the magnitudes of the triggering earthquake. Ward (2002) presented the attenuation curves of tsunami waves versus distance for different magnitudes using the previous achievement as well as the relation between attenuation and wavelength.

Tsunami magnitude is $m=\log _{10} 2 \times H$, where $H$ is the maximum run-up height measured at a coast $10-$ $300 \mathrm{~km}$ from the tsunami source (Murty, 1977). Soloviev (1970) pointed out the inappropriateness of the term 'tsunami magnitude'. "If seismological terminology is applied to description of tsunamis, the grades of the Imamura-Iida scale must be designated as the intensity of the tsunami and not its magnitude. This is because the latter value must characterize dynamically the processes in the source of the phenomenon and the first one must characterize it at some observational point, the nearest point to the source included." The tsunami intensity scale in Table 2 is from Soloviev (1978) and Alexander (1993).

\subsection{Preparing a computer code}

Concerning the model structure, a code has been written in Matlab software for calculating the height of a tsunami wave for each of the mentioned sources. The necessary input data are zone basin, ordinates of coastline and the specifications of sources. Bathymetry data are obtained by converting the geographical ordinates into UTM and using the codes in the form of $(x, y, z)$. The same was done for the ordinates of coastline and used as $(x, y)$.

The specifications of the sources are presented in two files: (1) the initial and ultimate coordinates, digitizing of source length into 100 metric intervals; (2) median depth, source length, earthquake magnitude and 
Table 2 Tsunami intensity scale (Soloviev, 1978; Alexander, 1993).

\begin{tabular}{|c|c|c|}
\hline Intensity & Run-up height/m & Description of tsunami \\
\hline $\mathrm{I}$ & 0.5 & Very slight. Wave so weak as to be perceptible only on tide gauge records. \\
\hline II & 1.0 & $\begin{array}{l}\text { Slight. Waves noticed by people living along the shore and familiar with the sea. On very flat } \\
\text { shores waves generally noticed. }\end{array}$ \\
\hline III & 1.0 & $\begin{array}{l}\text { Rather large. Generally noticed. Flooding of gently sloping coasts. Light sailing vessels carried } \\
\text { away on shore. Slight damage to light structures situated near the coast. In estuaries, reversal } \\
\text { of river flow for some distance upstream. }\end{array}$ \\
\hline IV & 4.0 & $\begin{array}{l}\text { Large. Flooding of the shore to some depth. Light scouring on made ground. Embankments and } \\
\text { dykes damaged. Light structures near the coast damaged. Solid structures on the coast lightly } \\
\text { damaged. Large sailing vessels and small ships swept inland or carried out to sea. Coasts littered } \\
\text { with floating debris. }\end{array}$ \\
\hline $\mathrm{V}$ & 8.0 & $\begin{array}{l}\text { Very large. General flooding of the shore to some depth. Quays and other heavy structures near } \\
\text { the sea damaged. Light structures destroyed. Severe scouring of cultivated land and littering of } \\
\text { the coast with floating objects, fish and other sea animals. With the exception of large ships, all } \\
\text { vessels carried inland or out to sea. Large bores in estuaries. Harbour works damaged. People } \\
\text { drowned, waves accompanied by a strong roar. }\end{array}$ \\
\hline VI & 16 & $\begin{array}{l}\text { Disastrous. Partial or complete destruction of man-made structures for some distance from the } \\
\text { shore. Flooding of coasts to great depths. Large ships severely damaged. Trees uprooted or } \\
\text { broken by the waves. Many casualties. }\end{array}$ \\
\hline
\end{tabular}

the height of the wave coming from the source (based on the calculations of previous section).

The procedure assumes, first, that the nearest source point was a linear source for any coastal points and their distances are considered as the travel distance of the wave. The wave attenuation was then calculated to pass from mentioned distance. The low bathing coefficient was computed based on the depth of water in the source and coastal zone, with the amplitude increasing with decreasing water depth.

Based on where the coastal point is located relative to the position of four zones, its proper slope coefficient was selected. Finally, the height of tsunami wave from a particular source was calculated at certain coastal point using all above information. Repeating these calculations for the entire coastline, the map of tsunami wave height is obtained for each source. The output of the program was the coastline ordinates and the wave height $(x, y, z)$ of each point, which can be used in all preparing and plotting map software.

\subsection{Zoning}

The items used for zoning are the height of $0-0.5$ $\mathrm{m}$ (non sensible), $0.5-1 \mathrm{~m}$ (the wave height less than human being, sensible, low hazardous), 1-2 m (water height almost as human being tall, hazardless), and over $2 \mathrm{~m}$ (the height higher than human being and comparable with structural height, critical) (Table 3).

\subsection{Wave height}

As discussed earlier, the tsunami wave heights that originated from each potential source have been calculated along the coastline. The map of wave height was also prepared for each seismic source. The coastal hazard zoning maps have been prepared using the data of wave height in the shore based on the mentioned height range, and are shown in Figure 5. The assessment of possible tsunami height is performed and shown in Figure 5 a based on the source $L_{1}$ to be $\sim 1 \mathrm{~m}$. These heights are assessed to be $3 \mathrm{~m}$ for the source $L_{2}$ (Figure $5 \mathrm{~b}$ ), $1 \mathrm{~m}$ for the source $L_{3}$ (Figure $5 \mathrm{c}$ ), and $2 \mathrm{~m}$ for the source $L_{4}$ (Figure 5d). The maximum height for tsunami hazard levels is assessed and presented (Figure 6), which was obtained from the co-weighted averaging of the wave height caused by different scenarios. It should be mentioned that the width of the coastline has no physical meaning in the maps and serves only for better perspective.

Table 3 Height range used for preparing zoning map

\begin{tabular}{cccl}
\hline Wave height $/ \mathrm{m}$ & Hazard degree & Used color & Description \\
\hline $0-0.5$ & 0 & Blue & Non sensible \\
$0.5-1$ & 1 & Green & Wave height less than human tall, sensible, low hazardless \\
$1-2$ & 2 & Yellow & Wave height almost as human tall, hazardous \\
$>2$ & 3 & Red & Wave height more than human tall, comparable with the \\
\end{tabular}



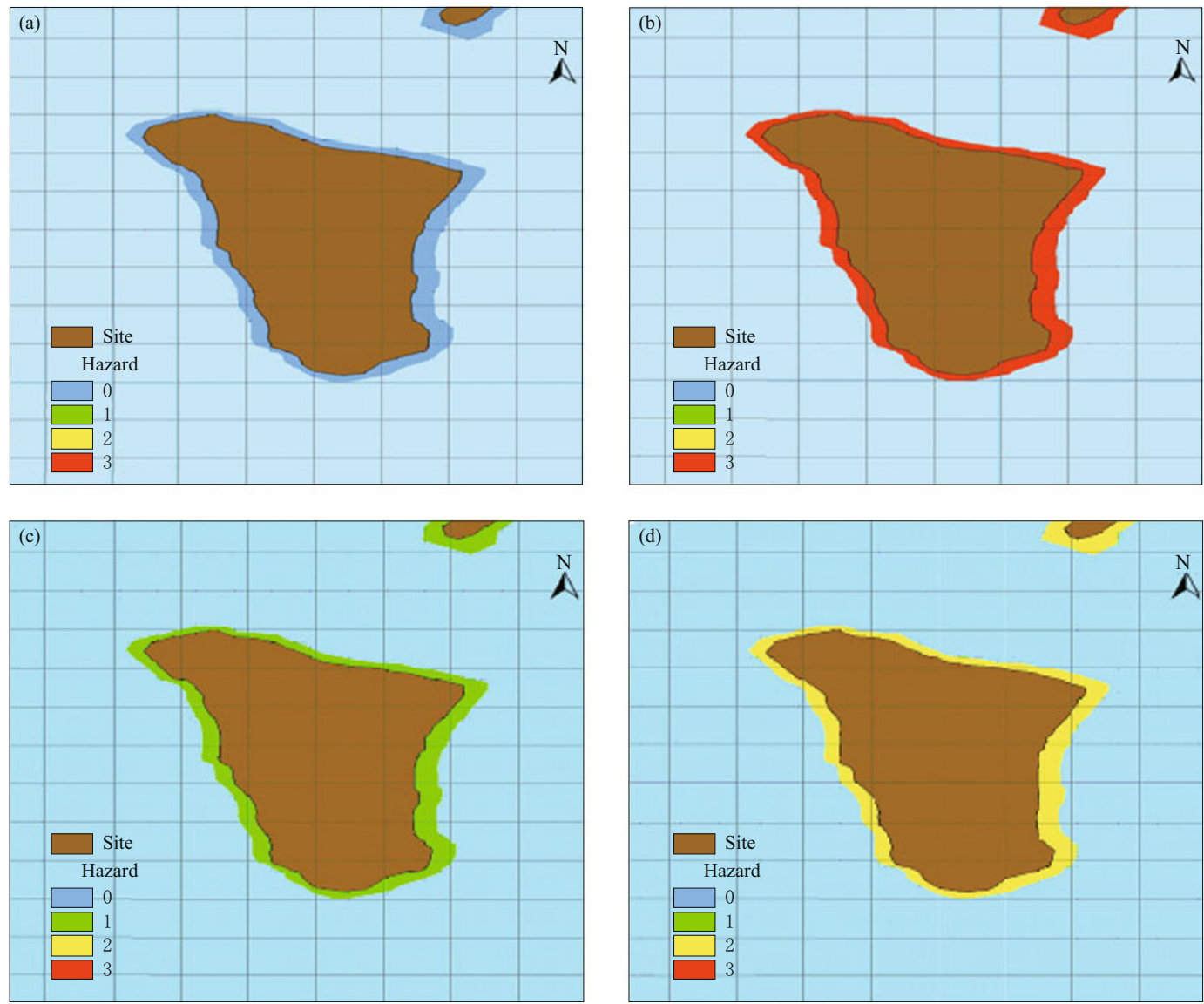

Figure 5 Tsunami hazard zoning map based of the activity of the sources $L_{1}$ (a), $L_{2}$ (b), $L_{3}$ (c) and $L_{4}$ (d).

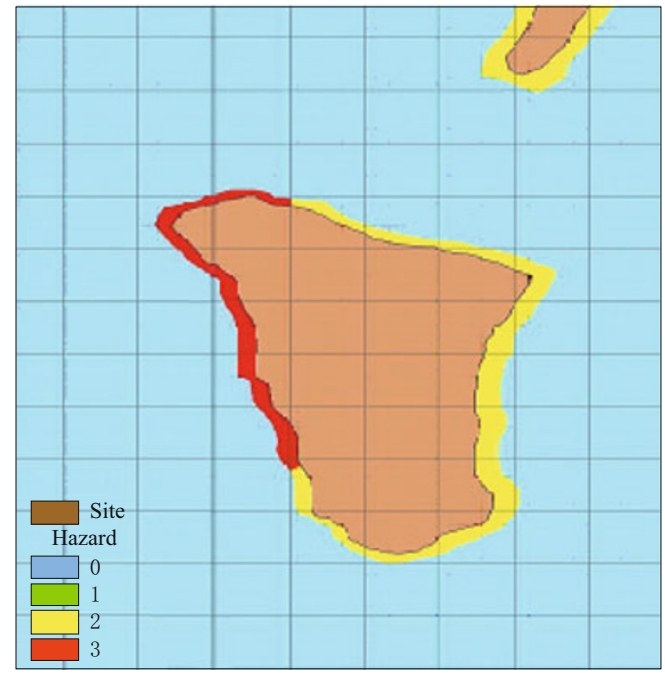

Figure 6 Map of the maximum expected hazard level determined from the co-weighted averaging of wave height caused by different scenarios.

\subsection{Uncertainty in the model}

The source of uncertainties in the tsunami hazard modeling can be assessed based on the epistemic uncer- tainties (due to the lack of data) and the aleatory uncertainties (due to the randomness of the natural phenomena). The modeling performed in this study was based on linear modeling. In such a simplified introductory study, the friction, local sinuosity of the coastline, complexity of the fault motion (especially in the horizontal component), and the possible fault rupturing on land (not offshore) are taken as the probable source of the tsunami. Therefore, the possible uncertainty sources in the model, which may cause the difference between the expected and the recorded values, are: (1) ignorance of nonlinearity in the model and the different types of breaking waves at the coast, (2) ignorance of the effects of friction and distribution, (3) ignorance of the effects of local topographic along the coast (reflection, refraction and dispersion), (4) assumption of fault rupture uniformity along the trace, (5) assumption of vertical slip motion for the focal mechanism of all faults, due to lack of information for the sea floor fault mechanisms, and (7) ignorance of the fault source on land (not offshore) because of the lack of information for such faulting. 
In a more thorough follow up study, more detailed data are expected in order to minimize the epistemic uncertainty. Alternatively, sophisticated models may be used in order to minimize the effects of the aleatory uncertainties.

\section{Conclusions}

With regards to the obtained results, the hazard distribution along the coastline and the hazard levels of each source are summarized as follows:

1) The maximum calculated wave height is $3.5 \mathrm{~m}$.

2) No serious hazard is posed to the structure by the sources $L_{1}$ and $L_{3}$ due to the shallow depths at these sites. The maximum potential wave height due to the sources $L_{1}$ and $L_{3}$ are 30 and $60 \mathrm{~cm}$, respectively.

3) The source $L_{2}$ was expected not to cause serious hazard; however, it was very close to the structure and the wave energies did not have enough time to be attenuated and therefore the expected wave height was up to $3 \mathrm{~m}$.

4) The source $L_{4}$ produced waves heights of almost $1.5 \mathrm{~m}$ at the structure, despite of its far distance. This is due to the expected magnitude of this source as well as its location in the deep waters of the Oman Sea.

On average, the 2 degree hazard (wave of 1-2 m heights) is seen along the most parts of the coast. However, the waves heights are very high adjacent to the source $L_{2}$, and a hazard degree of 3 degree (waves heights of $<2 \mathrm{~m}$ ) is expected.

Acknowledgements This study was financially supported through a contract between the Research and Development Section, Iranian Oil Terminals Company (IOTC), and the International Institute of Earthquake Engineering and Seismology (IIEES). Special thanks to the local and logistical support by the personal of the IOTC.

\section{References}

Alexander D (1993). Natural Disasters. UCL Press, London, $632 \mathrm{pp}$.

Ambraseys N N and Jackson J A (1998). Faulting associated with historical and recent earthquakes in the Eastern
Mediterranean region. Geophys J Inter 133: 390-406.

Liu-Zeng J, Heaton T and DiCaprio C (2005). The effect of slip variability on earthquake slip-length scaling. Geophys J Int 162: 841-849.

Mohajer-Ashjai A and Nowroozi A A (1978). The Tabas earthquake of September 16, 1978 in east-central Iran, A preliminary field report. Geophys Res Lett 6(9): 689-692, doi:10.1029/GL006i009p00689.

Motie H (1993). Stratigraphy of Zagros. Publications of Geological Survey of Iran, Persian, 536pp.

Murty T S (1977). Seismic Sea Waves: Tsunamis. Department of Fisheries and the Environment, Fisheries and Marine Service, Bulletin of the Fisheries Research Board of Canada, Ottawa, 198, 337.

Nowroozi A A and Mohajer-Ashjai A (1985). Fault movements and tectonics of eastern Iran: boundaries of the Lut plate. Geophys J R astr Soc 83: 215-237.

Soloviev S L (1970). Recurrence of tsunamis in the Pacific. In: Adams W M ed. Tsunamis in the Pacific Ocean. EastWest Center Press, Hololulu, 149-163.

Soloviev V (1978). Tsunamis. In: Savarenskij E F and Nersesov I L eds. The Assessment and Mitigation of Earthquake Risk. UNESCO, Paris, 277-288.

Takahasi R (1961). Report on the Chilean Tsunami of May 24, 1960 as Observed along the Coast Japan. Comm. Field Investig. of Chilean Tsunami of 1960, Tokyo, $395 \mathrm{pp}$.

Ward S N (2002). Tsunamis. In: Meyers R A ed. The Encyclopedia of Physical Science and Technology. Academic Press, Salt Lake City, 175-191.

Wells D L and Coppersmith K J (1994). New empirical relationships among magnitude, rupture length, rupture width, and surface displacements. Bull Seismol Soc Am 84: 974-1 002.

Yanovskaya T B, Romanelli F and Panza G F (2003). Tsunami excitation by inland/coastal earthquakes: the Green function approach. Nat Hazards Earth Syst Sci 3: 353-365.

Zaré M (2003a). Construction in the active fault zones (Case-Studies in Tehran and Tabriz); empirical relationships for estimation of fault-rupture hazard zones in Iran. In: Proceedings of the 1 st Seminar on Construction in Capital. Tehran, February 2003, 12-24.

Zaré M (2003b). An Introduction to the Applied Seismology. International Institute of Earthquake Engineering and Seismology, Tehran, 300pp (in Persian). 